\title{
Hospital malnutrition at pediatric ward Dr. Wahidin Sudirohusodo Hospital Makassar
}

\author{
Aidah Juliaty Wahyudin*, JS Lisal \\ From 7th APPES Biennial Scientific Meeting \\ Nusa Dua, Bali. 14-17 November 2012
}

\section{Background}

Hospital Malnutrition (HM) is one of the health problems in hospital care. Malnutrition in hospital leads to many problems like prolonged length of stay, clinical complications, delayed recovery and increase economic cost.

\section{Objective}

To determine nutritional status on admission and monitoring their weight changes, in order to reveal incidence of hospital malnutrition.

\section{Methods}

A prospective study was conducted in January until December 2011 period. The initial measurement were made by residents in charge. The nutritional status was defined according to CDC 2000 guidelines. Exclusion criteria including children with fluid retention, organomegaly, obesity, and tumours. HM was defined as weight decreased $\geq 2 \%$ for LOS (length of stay) less than 7 days, $\geq 5 \%$ for LOS 7 to 30 days and $\geq 10 \%$ for LOS 1 to 6 months. Data were analyzed using SPSS for Windows.

\section{Results}

From 1286 patients hospitalized during the period, most of them $(81,5 \%)$ suffer for weight loss $\geq 2 \%$. According to age, HM occurs more in 25 - 36 months age group $(0,16 \%)$.

\section{Conclusion}

Incidence of HM still high, a close monitoring to patients intake and needs is necessary to prevent and to lower the incidence.

Published: 3 October 2013

Department of Child Health, Faculty of Medicine, Hasanuddin University, Dr. Wahidin Sudirohusodo Hospital, Makassar, Indonesia
doi:10.1186/1687-9856-2013-S1-P49

Cite this article as: Wahyudin and Lisal: Hospital malnutrition at pediatric ward Dr. Wahidin Sudirohusodo Hospital Makassar.

International Journal of Pediatric Endocrinology 2013 2013(Suppl 1):P49.
Submit your next manuscript to BioMed Central and take full advantage of:

- Convenient online submission

- Thorough peer review

- No space constraints or color figure charges

- Immediate publication on acceptance

- Inclusion in PubMed, CAS, Scopus and Google Scholar

- Research which is freely available for redistribution
() Biomed Central 